Original Article

\title{
Quality of life and stress in caregivers of drug-addicted people*
}

\author{
Qualidade de vida e sobrecarga de cuidados em cuidadores de dependentes quimicos \\ Evaluación de la calidad de vida sobrecarga en los cuidadores de química dependientes
}

\author{
Samira Reschetti Marcon ${ }^{1}$, Elizete Aparecida Rubira ${ }^{2}$, Mariano Martinez \\ Espinosa $^{3}$, Angélica Belasco ${ }^{4}$, Dulce Aparecida Barbosa ${ }^{5}$
}

\begin{abstract}
Objective: To evaluate quality of life and presence of stress in caregivers of drug-addicted people. Methods: This cross-sectional study was carried out at four Psychosocial Care Centers in Mato Grosso. Demographic and quality of life data were collected for 109 caregivers using the Medical Outcomes Study 36 - Item Short-form, depression symptoms (Beck Depression Inventory) and stress of caregivers (Caregiver Burden Scale). Results: Of 109 caregivers, $55.9 \%$ were mothers with a mean age of 47.66 years; $23.8 \%$ had depressive symptoms. The SF36 scores most compromised were emotional aspects, vitality, pain and mental health. Mean stress among caregivers was 2.24 . A significant correlation in quality of life, depression and stress of caregivers was seen. Conclusion: Findings confirmed that quality of life is compromised and stress is high among caregivers, highlighting the need for providing emotional support.
\end{abstract}

Keywords: Caregivers; Quality of life; Family relations; Depression; Substance-related disorders

\section{RESUMO}

Objetivos: Avaliar a qualidade de vida e a presença de sobrecarga de cuidados em cuidadores de dependentes químicos. Métodos: Estudo de corte transversal, realizado em quatro Centros de Atenção Psicossocial de Mato Grosso, com 109 cuidadores. Foram coletados dados sociodemográficos, de qualidade de vida por meio do Medical Outcomes Studies 36 - Item Short-Form, sintomas de depressão (Inventário de Depressão de Beck) e sobrecarga do cuidador (Caregiver Burden Scale). Resultados: Dentre os 109 cuidadores, 55,9\% eram mães, idade média 47,6ㅁ anos e 23,8\% apresentaram sintomas depressivos. Os escores do SF36 mais comprometidos foram: aspectos emocionais, vitalidade, dor e saúde mental. A média geral da sobrecarga entre os cuidadores foi de 2,24. Houve correlação significativa nas dimensões da qualidade de vida, presença de depressão e sobrecarga de cuidado. Conclusão: Os achados confirmaram o comprometimento da qualidade de vida e alta sobrecarga de cuidado que evidenciam a necessidade de apoio emocional a esses cuidadores.

Descritores: Cuidadores; Qualidade de vida; Relações familiares; Depressão; Transtornos relacionados ao uso de substâncias

\section{RESUMEN}

Objetivos: Evaluar la calidad de vida y la presencia de sobrecarga de cuidados en cuidadores de dependientes químicos. Métodos: Se trata de un estudio de corte transversal, realizado en cuatro Centros de Atención Psicosocial de Mato Grosso, con 109 cuidadores. Fueron recolectados datos sociodemográficos, de calidad de vida por medio del Medical Outcomes Studies 36 - Item Short-Form, síntomas de depresión (Inventario de Depresión de Beck) y sobrecarga del cuidador (Caregiver Burden Scale). Resultados: De los 109 cuidadores, 55,9\% eran madres, con edad promedio de 47,6 años y 23,8\% presentaron síntomas depresivos. Los scores del SF36 más comprometidos fueron: aspectos emocionales, vitalidad, dolor y salud mental. El promedio general de la sobrecarga entre los cuidadores fue de 2,24. Hubo correlación significativa en las dimensiones de la calidad de vida, presencia de depresión y sobrecarga de cuidado. Conclusión: Los hallazgos confirmaron el compromiso de la calidad de vida y alta sobrecarga de cuidado que evidencian la necesidad de apoyo emocional a esos cuidadores.

Descriptores: Cuidadores; Calidad de vida; Relaciones familiares; Depresión; Trastornos relacionados consustancias

\footnotetext{
* This study was adapted from a doctoral degree dissertation entitled "Evaluation of quality of life of caregivers assisting drug-addicted people" Nursing departmentHealth Sciences - Universidade Federal de Sáo Paulo - UNIFESP - São Paulo (SP), Braz̨il.

${ }^{1}$ Nurse, PhD in Health Science. Adjunct Professor of Nursing Course of the Nursing Department, Universidade Federal de Mato Grosso - UFMT - Cuiabá - (MT).

${ }^{2}$ Nurse, PhD in Health Science. Adjunct Professor of Nursing Course of the Nursing Department, Universidade Federal de Mato Grosso-UFMT - Cuiabá - (MT).

${ }^{3}$ Statistician, Postdoctoral in reliability at Universidade de São Paulo - USP SP. Adjunct Professor of Statistics department, Universidade Federal Mato GrossoUFMT-Cuiabá - (MT).

${ }^{4}$ Nurse, Postdoctoral in Nephrology. Adjunct Professor of Nursing College, Universidade Federal de São Paulo - UNIFESP - São Paulo - (SP), Brazil.

${ }^{5}$ Nurse, Postdoctoral in Nephrology, Adjunct Professor of Nursing College, Universidade Federal de São Paulo - UNIFESP - São Paulo - (SP), Brazil.
} 


\section{INTRODUCTION}

The sociopolitical, economic and cultural history that involves drug problems is complex. It threatens quality of life (QL) within the population and is a severe public health problem ${ }^{(1)}$. Some studies highlight the wide repercussions of chemical dependency not only in users of psychoactive substances but also in family members who live with drug-addicted people ${ }^{(2,3)}$.

Family members who live with a drug addict are affected by the level of chemical dependency and how it has evolved and developed ${ }^{(2)}$; incalculable losses such as financial instability and physical, psychological and verbal violence all reduce QL, which constitutes a burden for both the family and the drug user ${ }^{(4)}$.

A study including families of chemical dependents found an increased risk of mental disorders, seen in 58\% of drug addict's spouses. In addition, a high frequency of physical aggression, death and problems involving the police are found in such homes ${ }^{(5)}$. In another study of spouses who take care of alcoholics, these women tended to get sick because of frequent pressures, anxieties and embarrassment, aggression, fears and frustrations related to relapses, and other reasons ${ }^{(3)}$.

Although the entire family structure is affected negatively in drug abuse situations, family members suffer in different degrees based on their closeness to the drug addict and distance from the addict's behavior. Most of the time, a member of the family assumes the role of caregiver, and he or she is most burdened from this process ${ }^{(4,6)}$.

Considering that the involvement of family is recommended for the recovery process of chemical dependents, it is necessary to appropriately evaluate the suffering and decreased QL of caregivers. However, published studies on caregivers of illicit drug users are scarce. This study aimed to evaluate QL and presence of stress in caregivers of chemical dependents.

\section{METHODS}

This cross-sectional study was carried out from August 2008 to September 2009 at four Psychosocial Care Centers for alcohol and drugs (CAPS AD, acronym in portuguese) in the municipalities of Mato Grosso, Brazil: Cuiabá, Várzea Grande, Rondonópolis and Barra do Garças.

The study population was composed of caregivers of illicit drug users who were being treated at CAPS AD. Drug dependents were interviewed, with caregivers defined as the person who was named for reference or responsible for follow-up of the drug dependents' treatment.

Based on calculation of users registered in the service, 109 caregivers were identified $(n=109)$. Because
CAPS AD had different population sizes, a stratified random sampling method was used proportional to the mean number of users registered in 2007. An estimation error of 0.05 , confidence of $95 \%$ and proportion of 0.5 was applied, and the inclusion criteria were individuals older than 18 years and who did not use illicit and/or legal substances. The study data were collected from August 2008 to September 2009.

Caregivers were contacted after the drug dependent individual gave permission. Caregivers were informed about the aim of the study, and those agreeing to participate signed the consent form. Interviews that lasted at least 50 minutes were conducted at CAPS AD by trained scholarship students in a private environment.

Sociodemographic data on QL were collected using the Medical Outcomes Study 36 - Item Short-Form Health Survey $y^{(7)}$, a multiprofessional instrument, translated into Portuguese and validated in Brazil in 1997. This instrument has 36 items divided in eight scales or domains: functional capability, physical aspects, pain, general health status, vitality, emotional and social aspects, and mental health. Scores varied from 0 (worst status) to 100 (best status).

The Beck Depression Inventory ${ }^{(8)}$ (BDI) was used to investigate the presence of depressive symptoms. This inventory has 21 items that include symptoms and behaviors. Answers may vary from zero (no symptoms) to three (more severe depressive symptoms), with the total score having cut-off points to indicate level of depression. In this study, cut-off points were as follows: $<15=$ normal or mild depression, $16-20=$ dysphoria, and $>20=$ depression .

The Caregiver Burden Scale ${ }^{(9)}$ (CBS) was used to assess care burden. This scale has 22 questions that are subdivided into five dimensions: general tension, secluding, disappointing, emotional and environmental involvement. It has partial and total scores ranging from one (absence of burden) to four (bigh burden).

Descriptive and inferential analyses were done to characterize sample data. For the descriptive analysis, we considered percentages, position measures and variation. For the inferential analysis, Spearman correlation techniques and multiple linear regression were used; in all cases, $\mathrm{p}<0.05$ was considered significant. The SPSS program version 14 and the MINITAB version 14 were used for statistical analyses.

This study was approved by the Research and Ethical Committee of the Universidade Federal de São Paulo, number 0556/07. All participants signed the consent form.

\section{RESULTS}

Caregivers were predominantly women $(90.8 \%)$ with a mean age of 47.6 years; $68.8 \%$ were married, 
and $77.0 \%$ were employed. Among caregivers, 23.8\% had depressive symptoms and $12.8 \%$ had dysphoria (Table 1).

Table 1. Sociodemographic characteristics and presence of depressive symptoms in caregivers of drug dependents

\begin{tabular}{lc}
\hline Variable & $\mathbf{n}^{\mathbf{0}}(\mathbf{\%})$ \\
\hline Sex & \\
Women & $10(90.8)$ \\
Men & \\
Race & $65(59.6)$ \\
Not White & $44(40.3)$ \\
White & \\
Marital status & \\
Married & $75(68.8)$ \\
Single & $34(31.1)$ \\
Employed & \\
Yes & \\
No & $25(22.9)$
\end{tabular}

Education

No formal education
Incomplete primary school
Primary school degree
High school degree
College degree

Income $(\bar{\chi} \pm \mathrm{DP})$

Age $(\bar{\chi} \pm$ DP $)$

$780 \pm 1509$

Relationship type

Mother

$61(55.9)$

Spouse

$20(18.3)$

Others

$28(25.6)$

Presence of depressive symptoms
Depression
$26(23.8)$
Dysphoria
$14(12.8)$
Normal
$69(63.3)$

Data in table 2 show SF36 scores were more affected in the following domains: emotional aspects (44.6 \pm $4.0)$, vitality $(52.8 \pm 2.3)$, pain $(54.1 \pm 2.4)$ and mental health $(55.3 \pm 2.3)$. The mean domain scores of caregiver burden scale highlighted emotional involvement (2.5) and general tension (2.4) as most compromised. The mean general burden among caregivers was 2.2.

Table 2. Mean values of SF36 domains and general score of caregiver burden

\begin{tabular}{lc}
\hline Variable & Mean \pm EPM* \\
\hline SF36 domains* & $69.8 \pm 2.34$ \\
Functional capabilities & $55.9 \pm 3.81$ \\
Physical aspects & $54.1 \pm 2.41$ \\
Pain & $61.7 \pm 2.10$ \\
General health status & $52.8 \pm 2.30$ \\
Vitality & $62.3 \pm 2.38$ \\
Social aspects & $44.6 \pm 4.02$ \\
Emotional aspects & $55.3 \pm 2.36$ \\
Mental health &
\end{tabular}

\section{Burden domains**}

General tension

$2.4 \pm 0.08$

Secluding

$2.1 \pm 0.10$

Disappointing

$2.1 \pm 0.08$

Emotional involvement

$2.5 \pm 0.08$

Enviroment

$2.0 \pm 0.07$

General mean

$2.2 \pm 0.07$

"SF-36 ("Medical Outcomes Study - 36 item Short-Form Survey"). *CBS (Cargiver Burden Scale). ***EPM: Standard error of the mean

Data in table 3 show the correlation among SF36 score domains with the Beck depression inventory, and caregiver general burden using a coefficient of Spearman correlation $(\varrho)$. A strong correlation $(\mathrm{p}<0.01)$ was observed in all SF36 domains, with mental health, emotional aspects and vitality more strongly correlated with the presence of depressive symptoms. Mental health domains, social aspects and general health status were more strongly correlated with care burden. 
Table 3. Spearman correlation coefficient among SF36 domains, Beck depression inventory (BDI) and general score of caregiver burden

\begin{tabular}{|c|c|c|c|c|}
\hline SF36 dimension & BDI correlation & $\mathrm{p}$ value & CBS correlation & $\mathrm{p}$ value \\
\hline Functional capability & -0.421 & $<0.001$ & -0.283 & 0.003 \\
\hline Physical aspects & -0.430 & $<0.001$ & -0.306 & 0.001 \\
\hline Pain & -0.442 & $<0.001$ & -0.351 & $<0.001$ \\
\hline General health status & -0.508 & $<0.001$ & -0.500 & $<0.001$ \\
\hline Vitality & -0.632 & $<0.001$ & -0.487 & $<0.001$ \\
\hline Social aspects & -0.517 & $<0.001$ & -0.552 & $<0.001$ \\
\hline Emotional aspects & -0.535 & $<0.001$ & -0.388 & $<0.001$ \\
\hline Mean health & -0.712 & $<0.001$ & -0.570 & $<0.001$ \\
\hline
\end{tabular}

SF-36 ("Medical Outcomes Study - 36 item Short- Form Survey"). CBS=Cargiver Burden Scale, BDI= Beck Depression Inventory.

Multiple linear regression analysis show that variables that more affected SF36 score domains were care burden $(36.5 \%)$, health problems $(6.3 \%)$, and caregiver gender $(2.0 \%)$ (Table 4$)$.

Table 4. Multiple linear regression analysis of SF36 domains regarding caregiver burden scale (CBS), sociodemographic variables and relative variables to caregiver health

\begin{tabular}{ccccc}
\hline Variable & Coefficient & $\begin{array}{c}\text { Coefficient } \\
\text { of Standard } \\
\text { Deviation }\end{array}$ & p value & $R^{2}$ \\
\hline $\begin{array}{c}\text { Total burden } \\
\text { (CBS) }\end{array}$ & -0.73217 & 0.0968 & $<0.001$ & 36.52 \\
$\begin{array}{c}\text { Health } \\
\text { problems }\end{array}$ & -9.92100 & 3.1350 & 0.002 & 6.33 \\
Gender & -10.40900 & 5.2600 & 0.049 & 2.05 \\
\hline
\end{tabular}

Note: An additional analysis was performed to verify adequacy of this model; after this analysis the model was considered adequate. The $b_{0}=109.371$ value and coefficient of determination value of $44.90\left(\mathrm{R}^{2}=44.90\right)$ had a sample standard deviation of 15.5219 (s $=15.5219), F 3.105=3.97$ and $\mathrm{p}$ value of 0.01 . The use of a general model could explain $44.90 \%$ of effect measured by total of SF36 domains experienced by the caregiver.

\section{DISCUSSION}

This study conducted at four CAPS AD in the Mato Grosso state used different scales of assessment to evaluate caregivers of drug-addicted people. Unfortunately, studies in Brazil using the same methodology were not identified.

In this study some methodological limitations must be considered, for example, bibliographic searching showed a limited number of studies on the subject and, among those found, comparison to this study was difficult because of the different design, method and instruments used. In order to have a parameter for data analyses we used studies of caregivers of chronic patients.

In this study, more caregivers were married women, consistent with the strong presence of women taking care of family members ${ }^{(4,10)}$ found in the literature. Employed caregivers who had mean income of $\mathrm{R} \$ 780.00$ were different from other caregivers for chronic patients who, in most of cases, were domestic workers ${ }^{(11,12)}$.

It is important to emphasize that the type of care for users who are dependent on psychoactive substances is different from that for those with other chronic diseases, such as dementia, AIDS and kidney disease (and who are not drug dependent). Although drug addicted people cause many problems, they do not consider themselves ill, and their families do not consider them as $\operatorname{sick}^{(10)}$. Therefore, the care of drug-addicted people typically does not directly interfere in the daily life of caregivers (work, home organization, among others activities). This is in contrast to the situation with chronic disease patients, because of their greater need for physical care.

The mean age of caregivers (47.6 years) was higher in this study than in another study of families of chemical dependents $^{(2)}$ (26-35 years). The fact that most caregivers in this study were mothers could explain this finding, considering that in the other study caregivers were wives/common law wives. However, two other studies with caregivers of Alzheimer's patients showed a higher mean age (57.4 and 51.3 years) ${ }^{(11,13)}$.

Depressive symptoms were seen in $23.8 \%$ of caregivers. Such symptoms could compromise the relation- 
ship of the caregiver with the chemical dependent, in addition to negatively affecting the caregivers' perception of their QL. A research on QL including families of drug-addicted people that used diagnostic criteria of CID-10(2) found depression in $23 \%$ of individuals, which is consistent with the results of our study. These data, when compared with results of reports of caregivers assisting patients with dementia, ${ }^{(11,14)}$ are slightly lower. In the literature depression is reported in 30\%$55 \%$ of caregivers ${ }^{(13)}$.

In QL investigation, the most compromised domains are emotional aspects, vitality, pain and mental health. While QL has been evaluated in different populations of caregivers of chronic diseases ${ }^{(9,11)}$, evaluations of caregivers of chemical dependents are scarce, and most that are found are often related to alcohol dependents ${ }^{(1,3-4,10)}$. In addition, use of a qualitative approach makes comparing populations difficult.

A study on QL evaluation among caregivers of chemical dependents using the WHOQOL-Bref ${ }^{(2)}$ showed better scores for physical domain (14.4) and poorer scores for social(13.2), psychological (12.5) and environmental (10.6). Another study with caregivers of hemiplegic patients ${ }^{(15)}$ had lower SF-36 scores in vitality (51.7), functional capability (53.8), mental health (56.8) and emotional aspects (55.8). Despite these differences, studies that evaluated QL among caregivers agree that those responsible for dependents have a significantly compromised QL, especially regarding emotional aspects and mental health ${ }^{(9)}$. In this study, caregivers' emotional aspect was more compromised than that of caregivers of chronic patients ${ }^{(11,15)}$.

In the investigation of care burden, the general mean was 2.2, and emotional involvement (feelings as shame and anger) and general tension (feelings of responsibility, exhaustion, facing problems difficult to resolve, injuries to health, lack of time, among others) were considered predictors of burden. In this study, the mean observed was higher than the one found in studies with caregivers of hemodialysis patients $(2.07)^{(16)}$ and caregivers of lower limb amputated patients (1.96) ${ }^{(17)}$ using the same instrument applied in this study.

Correlations between SF36 dimensions and the BDI were negative and significant in all dimensions, with mental health, vitality and emotional aspects more strongly correlated. A study including caregivers of Alzheimer's patients ${ }^{(11)}$ also had correlation in all SF36 dimensions, with mental health $(\mathrm{p}=0.000)$, vitality $(\mathrm{p}=0.000)$ and pain $(\mathrm{p}=0.000)$ the most compromised, which agree with results that were observed in this study. Other studies confirmed the correlation between QL and presence of depressive symptoms ${ }^{(14)}$.

A strong correlation was also seen between SF36 and CBS in all domains, with mental health, social aspects and general health status correlated with care burden. A study that compared QL and care burden of patients with epilepsy by Mesial Temporal Sclerosis and Juvenile Myoclonic Epilepsy, using the SF36 and Zarit Burden Interview (an instrument that evaluates the relationship between the caregiver and the patient, health condition, psychological well-being, finances and social life), had significant correlation only for the domains of general health status $(p=0.011)$, emotional aspects $(p=0.037)$ and mental health $(\mathrm{p}=0.002)^{(18)}$. Therefore, we concluded that overburdened individuals delivering care who also have the presence of depressive symptoms had a lower subjective perception of their QL, especially in mental health and emotional aspects.

Mental and emotional health significantly affect QL because they are linked directly to the illness process and loss of ability to face an environment that may include conflict, threat, disqualification, jealousy and relapses, which cause emotional distance and loss of hope. ${ }^{(10)}$ Mental and emotional health of caregivers must be strengthened to improve their relationships with and capability of providing care to a family member ${ }^{(19)}$.

In the multivariate linear analysis of scores of SF36 domains, considering care burden function, sociodemographic variables and variables related to caregiver health, findings show that domains of scale of burden $(36.5 \%)$, health problems $(6.3 \%)$ and caregiver's gender $(2.0 \%)$ affected QL but were variable; however overall compromised QL among caregivers was $44.9 \%$. A study with caregivers of patients who required care themselves in the Family Health Program ${ }^{(12)}$ showed that statistical variables related to the general index of QL were the burden scale, the Zarit Burden Interview, a sick caregiver and presence of someone to take care of that caregiver; the latter contributed favorably to caregiver QL.

When a physical problem is found, it appears that it may be caused by emotional aspects. People are biological, emotional and social beings and if any of these spheres are compromised, the problem might affect the person as a whole ${ }^{(19)}$. A study of caregivers of people with mental disorders ${ }^{(19)}$ found that diseases among the caregivers are related to the nervous system or gastrointestinal problems. Therefore, emotional aspects reflect directly on physical health. Attention to caregiver health is needed and should involve a multiprofessional team to best evaluate their health status, including the effect of both physical disease and mental health, which can interfere with caregiving and the QL of caregivers ${ }^{(12)}$.

The study of caregivers of Alzheimer's patients confirmed that QL is more negatively affected for female caregivers than for male caregivers ${ }^{(11)}$. Other studies also report that female caregivers are subjected to a high burden compared with male caregivers ${ }^{(13)}$. 


\section{CONCLUSION}

In this study, caregivers of drug dependents had lower scores than caregivers of chronic patients evaluated in other studies. They also showed higher care burden and strong correlation among their QL, care burden and depressive symptoms. The care burden scale, health problems, and caregiver gender corresponded

\section{REFERENCES}

1. Gonçalves AM, Luís MA, Sena RR. Doença mental e uso de álcool e outras drogas: dificuldades relatadas por mulheres cuidadoras em família. REME Rev Min Enferm. 2003; 7(1):14-20.

2. Aragão AT, Milagres E, Figlie NB. [Quality of life and hopelessness of relatives of addicted]. Psico-USF. 2009; 14(1):117-23.Portuguese.

3. Lima RA, Amazonas MC, Motta JA. Incidence of stress and stressful sources in alcoholics' wives]. Estud Psicol (Campinas). 2007; 24(4):431-9. Portuguese.

4. Miranda FA, Simpson CA, Azevedo DM, Costa SS. [The negative impact of the disturb of the use and abuse of the alcohol in the family coexistence]. Rev Eletr Enf [Internet]. 2006 [cited 2012 Set 10]; 8(2):222-32.Portuguese. Disponível em: http://www.fen.ufg.br/revista/revista8_2/v8n2a07.htm.

5. Figlie N, Fontes A, Moraes E, Payá R. [Children of Addicted Parents with Bio-psychosocial Risk Factors: Do Theyneed a Special Care?]. Rev Psiquiatr Clín. 2004; 31(2):53-62. Portuguese.

6. Campos PH, Soares CB. [Social representations of "family burden" and adhesion to mental health alternative services]. Psicol Rev. 2005; 11(18):219-37.

7. Ciconelli RM, Ferraz MB, Santos W, Meinão I, Quaresma MR. [Brazilian-Portuguese version of the SF-36. A reliable and valid quality of life outcome measure]. Rev Bras Reumatol. 1999; 39(3):143-50.Portuguese.

8. Gorestein C, Andrade L. Inventário de depressão de Beck: propriedades psicométricas da versão em português. Rev Psiquiatr Clín (São Paulo).1998; 25(5):245-50.

9. Belasco A, Barbosa D, Bettencourt AR, Diccini S, Sesso R. Quality of life offamily caregivers of elderly patients on hemodialysis and peritoneal dialysis. Am J Kidney Dis. 2006; 48(6):955-63. to $44.9 \%$ of compromised QL among caregivers. These results reinforce the importance of taking care of the population of caregivers for drug dependents. Finally, considering the scarce information available on caregivers of drug dependents and the compromised QL among this population, further research is needed to better understand their needs and identify specific measures to improve their QL.

10. Santos EC, Martin E. [Caregivers of alcohol addicted patients in the city of Santos, SP, Brazil]. Rev Bras Enferm. 2009; 6(2):194-9. Portuguese.

11. Pinto MF, Barbosa DA, Ferreti CE, Souza LF, Fram DS, Belasco AG. Quality of life among caregivers of elders with Alzheimer's disease. Acta Paul Enferm. 2009; 22(5):652-7.

12. Amendola F, Oliveira MA, Alvarenga MR. [Quality of life of family caregivers of patients dependent on the family health program]. Texto \&Contexto Enferm. 2008; 17(2):266-72. Portuguese.

13. Garrido R, Menezes PR. Impact on caregivers of elderly patients with dementia treated at a psychogeriatric service]. Rev Saúde Pública. 2004; 38(6):835-41. Portuguese.

14. Takahashi M, Tanaka K, Miyaoka H. Depresssion and associated factors of informal caregivers versus profissonal cargivers of demented patients. Psychiatry Clin Neurosci. 2005; 59(4):473-80.

15. Makiyama TY, Battisttela LR, Litvoc J, Martins LC. [A study about quality of life in hemiplegic stroke patientsand their caregivers]. Acta Fisiatr. 2004; 11(3):106-9. Portuguese.

16. Belasco AG, Sesso R. Burden and quality of life of caregivers for hemodialysis patients. Am J Kidney Dis. 2002; 39(4): 805-12.

17. Foss MH, Martins MR, Mazaro LM, Martins MI,Godoy JM. [Quality of life of lower limb amputees' caregivers] Rev Neurocienc. 2009; 17(1):8-13. Portuguese.

18. Westphal AC, Alonso NB, Silva Tl, Azevedo AM, Caboclo LO, Garzon E, et al. Comparação da qualidade de vida e sobrecarga dos cuidadores de pacientes com epilepsia por esclerose mesial temporal e epilepsia mioclônica juvenil. J Epilepsy Clin Neurophysiol. 2005; 11(2):71-6.

19. Borba LO, Schwartz E, Kantorski LP. Stress on families living with the reality of mental disorder. Acta Paul Enferm. 2008; 21(4):588-94. 